\title{
Desglaçant la literatura a les classes de llengua
}

\author{
Paula Marqués Hernández \\ Università Ca' Foscari Venezia \\ paula.marquesher@unive.it \\ ORCID: 0000-0003-2400-7648
}

Rebut: 10 de desembre de 2020

Acceptat: 19 de gener de 2021

\section{Resum}

Aquestes línies plasmen l'experiència didàctica sobre una activitat literària a l'aula de CLE de la Universitat Ca' Foscari de Venècia, duta a terme durant el curs 2019/2020. Els estudiants van assistir a la presentació de Permagel d'Eva Baltasar i, després d'unes sessions de reflexions i anàlisis conjuntes, van escriure'n una ressenya, col-locant a la base del seu discurs un dels temes del llibre esmentat a classe.

\section{De la presentació d'un llibre a l'aula: com naix l'activitat}

Abans de ser professora de llengua a la universitat Ca' Foscari de Venècia, ho vaig ser de literatura catalana durant un semestre. És ací on vaig tenir un primer contacte amb l'ensenyament de la literatura catalana a l'estranger i vaig trobar-me amb molts reptes. Ara bé, els més importants van ser dos: només un percentatge menor dels estudiants cursava català com a llengua estrangera i les lletres catalanes comptaven (i compten) encara amb poques traduccions a l'italià.

El que ens interessa ara, però, ja no és com la llengua entra en les classes de literatura, sinó a l'inrevés, com la literatura ha envaït les meues classes de llengua. Tot i que en les classes de CLE les lectures són sempre en llengua original, aquesta vegada, el punt de partida va ser la traducció a l'italià de Permagel, d'Eva Baltasar, acabada de sortir del forn a l'estiu del 2019 i la presentació del volum en una llibreria de Venècia. Vam convidar els estudiants a la presentació i allà van tenir un primer contacte real amb l'autora i amb el circuit literari català actual, un contacte previ a la lectura de l'obra.

\section{Objectius de l'activitat}

A Venècia, l'assignatura de Llengua Catalana és anual i abraça un notable ventall d'activitats per posar en marxa l'aprenentatge de l'estudiant i el progrés individual i col-lectiu en totes les competències lingüístiques. Així doncs, els objectius d'aquesta proposta didàctica havien de ser també transversals i havien de ser tant un repte per a la docent com per a l'alumnat. En 
primer lloc, jo em vaig marcar el desafiament de conèixer les potencialitats i les dificultats que té el contacte entre les cultures catalana i italiana en l'ensenyament/aprenentatge de CLE. En segon lloc, pretenia desenvolupar estratègies formatives i d'adquisició per poder facilitar la comunicació intercultural i el repte de comprendre i valorar el paper de la literatura catalana com a instrument per al desenvolupament de la competència lingüística i l'aproximació al context sociocultural d'una llengua viva i normal. Cal que els estudiants senten que el català és una llengua viva i normal, que senten la literatura sense filtres, de manera directa. El principal repte, doncs, és donar la possibilitat a l'alumnat de CLE de nivell intermedi o avançat, de tenir-hi accés sense necessitat d'adaptacions (ni actualitzacions) que sovint se'ns proposen, que puguen llegir els textos en original, sobretot si es tracta d'estudiants que posseeixen una llengua romànica com a L1, com és el cas dels italianoparlants. Els objectius per als estudiants, per tant, són accedir al coneixement en català, comprendre obres literàries actuals que poden ensenyar-los a viure d'una manera més plena i enriquidora i posar en marxa totes les competències lingüístiques de la llengua catalana a través de la producció d'un text acadèmic, una ressenya.

\section{Estructura i desenvolupament de l'activitat}

L'activitat es divideix en dos grans blocs i en cinc sessions, cadascuna de 90 minuts, que alternen el treball autònom des de casa amb la presencialitat en l'aula. La primera i la segona sessió es van fer abans de la lectura de Permagel; en canvi, la tercera, la quarta i la cinquena van ser posteriors a l'experiència lectora. Durant aquestes sessions cada alumne havia de preparar l'esquelet de la seua pròpia ressenya a través d'unes tasques concretes. La primera sessió va ser presencial i es va fer una aproximació a l'activitat. Es va presentar l'activitat dins el seu context d'avaluació i de continguts i se'ls van donar els primers recursos: es va fer l'explicació teòrica documentada sobre com escriure una ressenya. A continuació es va demanar als alumnes dur a terme algunes activitats sobre l'estructura d'una ressenya, per assegurar-nos que no hi havia dubtes. Se'ls va demanar que desconstruïren una ressenya i que n'indicaren les diferents parts. En la segona sessió, també presencial, ja se'ls va fer entrar en joc. Férem un xicotet tast del llibre: emplenàrem la fitxa tècnica i vam veure una entrevista a l'autora (contextualitzàrem l'autora i el text). ${ }^{1}$ Es va convidar els estudiants ja a llegir el llibre i es va fer una pausa d'unes quantes setmanes abans de reprendre les sessions literàries. Amb la voluntat d'engrescar l'alumnat a ser participatiu i a involucrar-se en les classes i en els debats del món contemporani, després d'haver llegit el llibre es va fer a l'aula la tercera sessió on vam intercanviar unes primeres impressions a través d'un debat sobre l'experiència lectora, a través de qüestions senzilles com "Què t'ha semblat la novel·la?", "Has trobat gaires dificultats a l'hora de llegir-la?" i "T'ha provocat curiositats? Quines?".

A continuació, els estudiants van respondre, en grup, a unes preguntes sobre la novel.la, amb l'ajuda d'una entrevista a Eva Baltasar i de la Viquipèdia catalana. I per últim, entre ells van haver d'identificar els temes de la novel-la, escriure'n un resum i les reflexions. La quarta sessió es va realitzar des de casa perquè ja tenien el bastiment de la seua ressenya ben construït. Van haver de triar un dels temes exposats durant la tercera sessió, ${ }^{2}$ el van desenvolupar en unes deu línies aproximadament i es van endinsar en l'últim pas de l'activitat: redactar la ressenya. Durant la cinquena sessió, se'ls va proposar escriure, en grup, en italià una entrada amb el títol Eva Baltasar per a la Viquipèdia italiana. ${ }^{3}$

1 En el nostre cas, també vam participar en la presentació de la traducció a l'italià de Permagel a la Libreria Marco Polo de Venècia i vam tenir l'oportunitat de conèixer l'autora i xerrar amb ella, com s'ha indicat a la part introductòria de l'experiència.

2 Per exemple, a classe van sortir els temes següents: la ceguesa (obre i tanca el llibre); el sexe, buidat de tabús i de sublimitats, vist des de la seua essència que és el plaer, la màxima carnalitat; les relacions familiars; les relacions emocionals.

3 Podeu consular l'entrada en el següent enllaç: https://it.wikipedia.org/wiki/Utente:ISA CATLC 


\section{Recapitulació: resultats de l'activitat}

Si fem una revisió detallada dels avantatges i inconvenients de l'ús del material literari a l'aula de CLE, podrem constatar que només hi ha bons resultats, ja que és eficaç en tot procés d'adquisició de la llengua estrangera i l'alumnat pot reforçar els continguts lingüístics a partir dels textos: a redactar bé se n'aprèn llegint molt i escrivint més. ${ }^{4} \mathrm{~A}$ més a més, com hem avançat a les primeres línies, permet connectar els estudiants en el circuit literari català actual i, per tant, en la història de la literatura catalana i en la teoria de la literatura.

L'acollida de l'obra literària de l'activitat per part dels estudiants va ser molt positiva, tot i que van fer constar que el llenguatge i l'estil de la prosa de Baltasar no els va semblar gaire fàcil en determinats moments. Durant la realització de les tasques van comptar amb un seguiment latent de la docent i amb un detallat dossier disponible al Moodle i enllaços web útils. Com a tall de conclusió, hem pogut constar que els resultats van ser molt bons i que treballar amb obres actuals, tot i la dificultat del llenguatge literari i metafòric, estimula força l'alumnat i llavors el fruit és doble, s'aprèn i s'enforteix la llengua en un dels seus contextos reals i que li donen vida: la literatura. 
